OPEN ACCESS

Edited by: Les Kaufman,

Boston University, United States

Reviewed by:

Elena Bollati,

National University of Singapore,

Singapore

William F. Precht,

Dial Cordy and Associates Inc.

United States

${ }^{*}$ Correspondence:

Karen L. Neely

kneely0@nova.edu

Specialty section:

This article was submitted to

Coral Reef Research,

a section of the journal

Frontiers in Marine Science

Received: 03 March 2021

Accepted: 07 July 2021

Published: 02 August 2021

Citation:

Neely KL, Shea CP, Macaulay KA,

Hower EK and Dobler MA (2021)

Short- and Long-Term Effectiveness

of Coral Disease Treatments.

Front. Mar. Sci. 8:675349.

doi: $10.3389 /$ fmars.2021.675349

\section{Short- and Long-Term Effectiveness of Coral Disease Treatments}

\author{
Karen L. Neely ${ }^{1 *}$, Colin P. Shea ${ }^{2}$, Kevin A. Macaulay ${ }^{1}$, Emily K. Hower ${ }^{1}$ and \\ Michelle A. Dobler ${ }^{1}$ \\ 1 Halmos College of Natural Sciences and Oceanography, Nova Southeastern University, Fort Lauderdale, FL, United States, \\ ${ }^{2}$ Fish and Wildlife Research Institute, Florida Fish and Wildlife Conservation Commission, St. Petersburg, FL, United States
}

Since 2014, stony coral tissue loss disease (SCTLD) has led to large-scale mortality of over 20 coral species throughout the Florida Reef Tract. In 2019, in-water disease intervention strategies were implemented to treat affected corals. Two treatment strategies were employed: (1) topical application of an amoxicillin paste directly to disease margins, and (2) application of a chlorinated epoxy to disease margins as well as an adjacent "disease break" trench. Effectiveness of treatments on 2,379 lesions from 725 corals representing five species was evaluated using mixed effects logistic regression models which demonstrated substantially greater effectiveness of amoxicillin compared to chlorine-treated lesions across all species up to 3 months post-treatment. As a result of the failed chlorinated epoxy treatments, any new lesions that appeared during subsequent monitoring events were treated with amoxicillin paste, and all corals were monitored and treated as needed approximately every 2 months for up to 24 months. The health status of 1664 amoxicillin-treated corals during each monitoring event was used to model the probability of a coral being uninfected over time. Models included species and geographic regions as variables. The appearance of new lesions (reinfection rates) varied by species, and offshore sites showed greater reinfection rates than inshore sites; however, all sites and species exhibited a decreased probability of reinfection with time since initial treatment. We conclude that topical amoxicillin treatments are highly effective at halting SCTLD lesions and that through initial and follow-up treatments as needed, colonies and reef sites will progress toward a lower prevalence of SCTLD.

Keywords: stony coral tissue loss disease, disease treatment, antibiotics, chlorinated epoxy, mixed effects logistic regression model

\section{INTRODUCTION}

Coral diseases are found on reefs throughout the world and are one of the most rapid and prevalent sources of coral mortality, even among the myriad stressors that are driving the decline of reefs. The first report of coral disease was published in Squires (1965). Since then, diseases have been documented in over 100 coral species and over 50 different nations (Green and Bruckner, 2000; Bruckner, 2016). Even though disease is traditionally present in ecosystems, elevated prevalence and virulence has resulted in elevated "background" rates as well as increasingly common outbreaks that can affect coral cover and species diversity (Cróquer et al., 2005). Coral disease has led to substantial changes in reef communities, from localized declines in various species (Cróquer et al., 2005) to the widespread loss of over $90 \%$ of acroporid corals throughout the Caribbean (Aronson and Precht, 2001). 
Many coral diseases have correlations with environmental stressors. For example, some diseases have peak prevalence during and following periods of thermal stress; these include white pox (Patterson et al., 2002), yellow band (Cervino et al., 2004; Cróquer and Weil, 2009), white plague (Cróquer and Weil, 2009), black band disease (Boyett et al., 2007; Lewis et al., 2017), and potentially white band disease (Randall and van Woesik, 2015). Water quality is also likely to play a role in overall disease prevalence; white pox has been tied to human fecal matter (Patterson et al., 2002), elevated nutrients have been shown to increase the prevalence and severity of dark spot disease (Thurber et al., 2014), and white plague outbreaks in the lower Florida Keys have correlated with periods of enriched nitrogen loading (Lapointe et al., 2019). Projections indicate that diseaseconducive conditions are increasing rapidly and that disease is likely to be just as significant a driver of coral decline as bleaching (Maynard et al., 2015).

Despite this, successful identification of coral disease pathogens continues to be challenging (Richardson, 1998), and potential treatment options are rare. Some coral disease treatments have been conducted for experimental and diagnostic purposes. These have ranged across seven different coral diseases with varying levels of success (Figure 1). Treatment types can be classified as mechanical (e.g., removal of diseased tissue, shading, smothering, and creating trenches), chemical (antiseptics or antibiotics, sometimes included within a mechanical treatment), or biological (phage therapy). Most treatments to date have involved mechanical methods such as separating diseased tissue from healthy tissue or in some way covering the disease margin (Hudson, 2000; Muller and Van Woesik, 2009; Dalton et al., 2010; Williams, 2013; Miller et al., 2014; Aeby et al., 2015; Randall et al., 2018). Results using these mechanical treatments have ranged from ineffective to relatively successful. The use of antibiotics is common in treating human and animal diseases (including heavy prophylactic use in agriculture), but their usage, even experimentally, for coral diseases has been limited. Two treatments have been used diagnostically to determine the presence of a bacterial component in white band disease (Kline and Vollmer, 2011; Sweet et al., 2014), and a third was unsuccessfully used as a conservation effort for corals with black band disease (Gil-Agudelo et al., 2004). Biological control of bacterial pathogens in corals has also been tested using phage therapy, in which a viral phage is used to target the causative agent. On Red Sea corals affected with white plague, this has been shown to slow tissue loss (Atad et al., 2012), prevent transmission (Efrony et al., 2009), and halt disease when applied prophylactically or within early stages of infection (Efrony et al., 2007, 2009).

While not all historical coral disease treatments have resulted in disease cessation, the success of some demonstrates that field treatment of coral diseases, at least on targeted colonies, is possible. Though disease outbreaks are heavily managed for humans and agricultural biomass (both plant and animal), disease outbreaks within wildlife populations are generally left untouched. Though guidelines have been suggested for management at different stages of wildlife disease outbreaks
(Langwig et al., 2015), the relatively few instances of active management of an outbreak traditionally occur in cases in which:

1. Human or agricultural health is threatened by the wildlife outbreak. Examples include baiting foxes with an antihelmintic to reduce risk of human infection (Tackmann et al., 2001), releasing sterile flies to control an outbreak of screwworms in Florida key deer to prevent transmission to animal stock (Skoda et al., 2018), and widespread wildlife vaccinations in Europe and North America to reduce and/or eliminate terrestrial rabies (Sterner et al., 2009; Mähl et al., 2014).

2. Ecosystem services (including harvest of a resource) are threatened. Examples of various treatment efforts include culling, chemical application, and biological control for pine beetles in American forests (Fettig et al., 2013).

3. Rare and highly managed species are at risk. Examples include California condors vaccinated against West Nile virus (Chang et al., 2007), Ethiopian and red wolves vaccinated against rabies (Harrenstien et al., 1997; Haydon et al., 2006), black-footed ferrets vaccinated against sylvatic plague (Abbott et al., 2012), arctic foxes treated with antiparasitic drugs for mange (Goltsman et al., 1996), and environmental disinfection and antifungal treatments on Mallorcan midwife toads (Bosch et al., 2015).

Stony coral tissue loss disease (SCTLD) has emerged as a major threat to Caribbean coral reefs. First documented near Miami, Florida in 2014 (Precht et al., 2016), it spread over the next 5 years throughout the majority of the Florida Reef Tract (Muller et al., 2020; Neely et al., 2021). Beginning in 2018, observations of SCTLD were documented in Mexico (Alvarez-Filip et al., 2019) and subsequently throughout other regions of the northern Caribbean (Weil et al., 2019). Work to identify the pathogen is ongoing, but transmission experiments show that infection is possible through physical contact as well as through sterile seawater (Aeby et al., 2019). Mortality rates are high, resulting in extensive loss of colonies (Precht et al., 2016) and localized near-extinction of highly susceptible species (Neely et al., 2021). Coral cover, species diversity, and colony density have all declined significantly in affected areas (Walton et al., 2018; Alvarez-Filip et al., 2019; Heres et al., 2021). Given the threat presented by SCTLD to Caribbean reefs, unprecedented actions have been taken to understand and mitigate this disease. In Florida, these include interagency steering committees, coral rescue activities, and scaled-up propagation and restoration plans. The response has also included novel and large-scale efforts to save infected colonies in situ.

By utilizing and modifying methodologies from the literature and expanding aquarium practices of antibiotic dosing to develop a topical application (Miller et al., 2018), two disease intervention procedures were implemented on Florida Keys reefs in an attempt to arrest active SCTLD lesions. We compared the effectiveness of chlorinated epoxy treatments and antibiotic paste treatments on halting disease lesions, and assessed the long-term infection rates of treated colonies. 


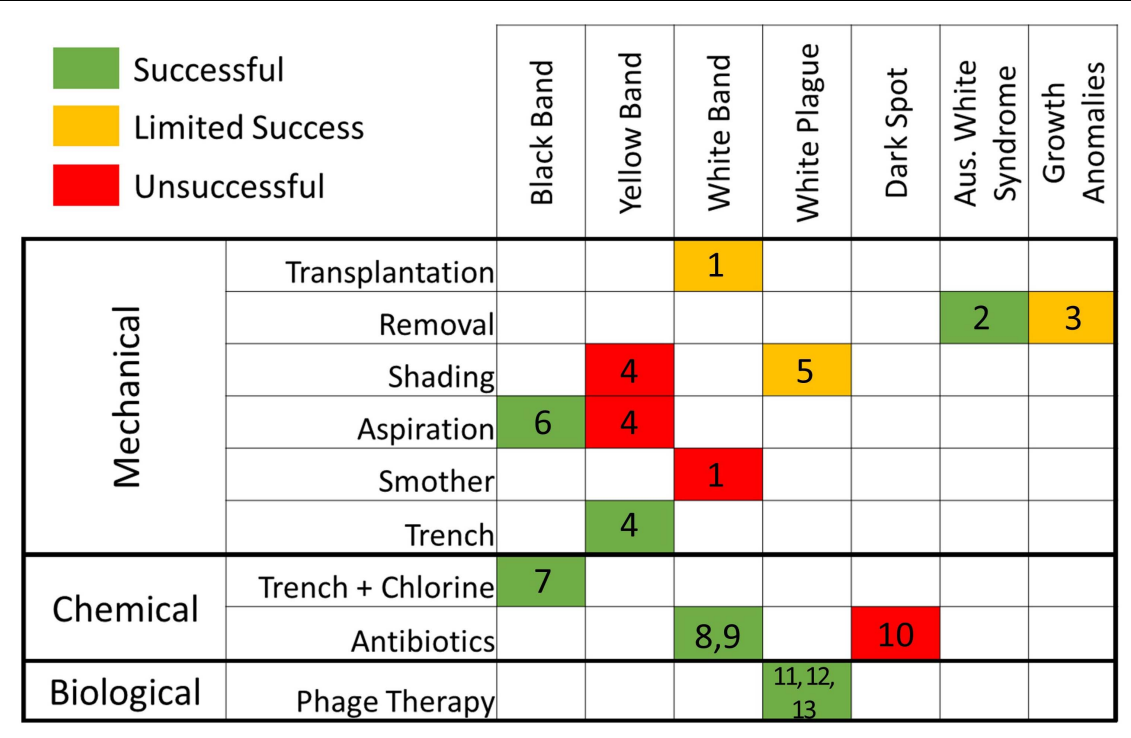

FIGURE 1 | Effectiveness of treatments on corals afflicted with seven diseases, as reviewed from the literature. Effectiveness is color coded as follows: green (effective), yellow (mixed results), red (ineffective). References: 1. Miller et al. (2014); 2. Dalton et al. (2010); 3. Williams (2013); 4. Randall et al. (2018); 5. Muller and Van Woesik (2009); 6. Hudson (2000); 7. Aeby et al. (2015); 8. Sweet et al. (2014); 9. Kline and Vollmer (2011); 10. Gil-Agudelo et al. (2004); 11. Efrony et al. (2007); 12. Efrony et al. (2009); 13. Atad et al. (2012).

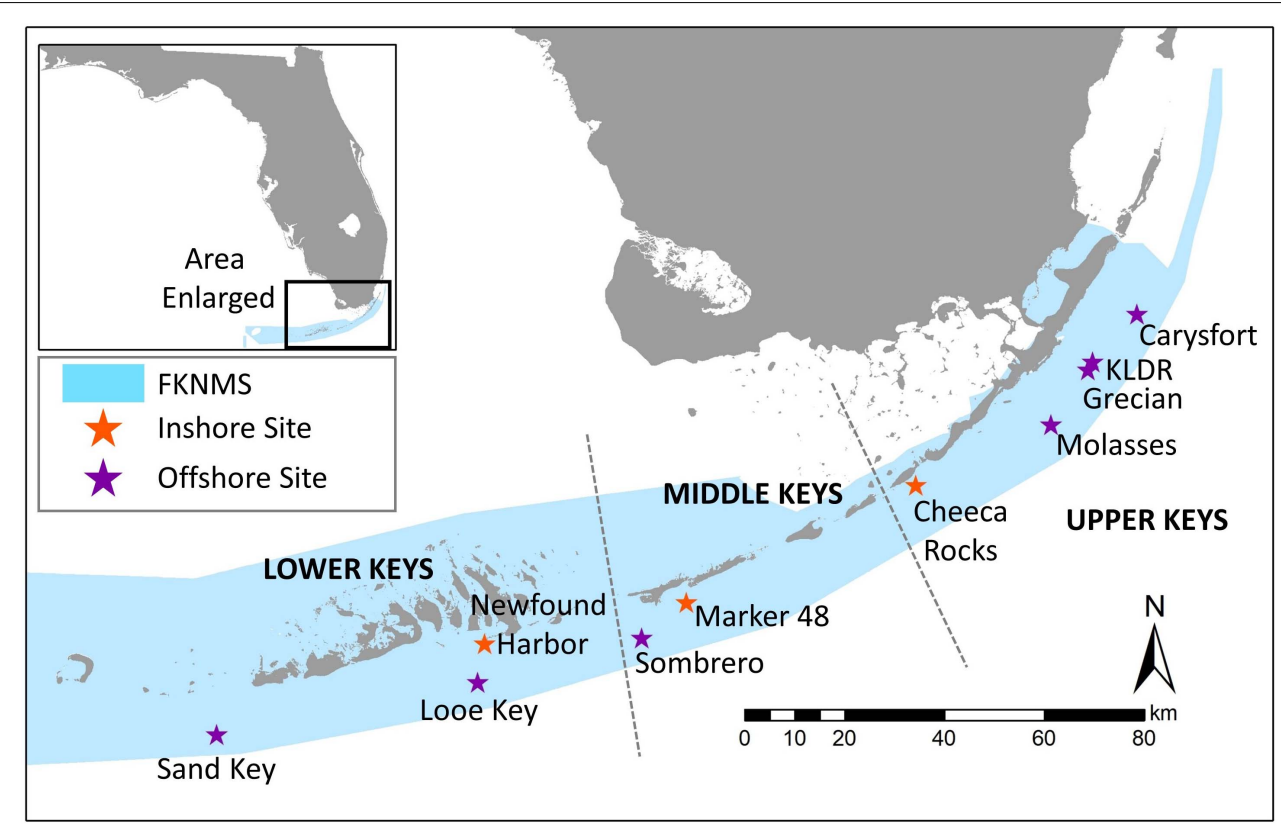

FIGURE 2 | Location of coral disease treatment sites within the Florida Keys National Marine Sanctuary (FKNMS). Regions are defined as lower, middle, and upper Keys. Colors represent inshore (orange) and offshore (purple) sites.

\section{MATERIALS AND METHODS}

\section{Sites and Treatments}

Ten sites throughout the Florida Keys National Marine Sanctuary (FKNMS) were selected for treatment (Figure 2). Sites ranged in depth from 4 to $12 \mathrm{~m}$. Most were located in no-take marine reserves; exceptions were Marker 48 as well as approximately half of the corals at Cheeca Rocks, which straddled the boundary of a no-take area. Initial treatments occurred between January 2019 and April 2020 (Table 1). As SCTLD spread through the FKNMS in a north to south gradient as well as an offshore to inshore gradient, reefs were not all experiencing the same level of disease during initial treatments; for example, offshore sites in the upper Keys were first treated several years after the arrival 
TABLE 1 | Dates and number of corals $(\mathrm{N})$ treated with amoxicillin paste and chlorinated epoxy treatments during the initial visits to each site.

\begin{tabular}{|c|c|c|c|c|}
\hline Site & Treatment dates & $\mathbf{N}$ amoxicillin & N chlorine & \# diseased corals per $100 \mathrm{~m}^{2}$ \\
\hline Upper Keys & January 2019 & 23 & 14 & 0.04 \\
\hline Sombrero & February 2019 & 61 & 46 & 0.35 \\
\hline Looe Key & February to April 2019 & 329 & 303 & 1.03 \\
\hline Sand Key & October 2019 & 23 & 0 & $\mathrm{~N} / \mathrm{A}$ \\
\hline Cheeca Rocks & April 2020 & 241 & 0 & 1.03 \\
\hline Marker 48 & April 2020 & 120 & 0 & 3.04 \\
\hline Newfound Harbor & April 2019 & 160 & 0 & 1.75 \\
\hline
\end{tabular}

of SCTLD while some inshore and southern sites were treated within a year of first appearance. Disease status during treatment of offshore sites in the upper Keys was similar, and so corals from Carysfort South, Grecian, Key Largo Dry Rocks, and Molasses are clumped for analysis. No pre-treatment prevalence data were taken, but considering that most to all of the diseased corals were treated, we used a GIS to estimate the area searched at each site and divided by the number of corals treated in order to estimate the density of diseased corals in an area (Table 1). Not all corals at Sand Key were treated and so no estimate is provided for that location.

Habitat characteristics surrounding each treatment site were analyzed in a GIS using the Unified Florida Coral Reef Tract Map v1.2 (Florida Fish and Wildlife Research Institute, 2014). For each treatment site, a $4 \mathrm{~km}$ buffer was overlaid on the habitat map's Level 1 classification scheme to determine the percentages of the surrounding radial area that were comprised of reef, pavement/unconsolidated substrate, seagrass, land, and offshore habitat.

At each treatment site, divers searched the reef to identify corals for treatment using the "priority coral guiding principles" outlined in the Coral Disease Intervention Action Plan (Neely, 2018). Treated corals were generally large, had a large amount of remaining live tissue, and were not overwhelmed with SCTLD lesions. At sites treated between January and April 2019, each coral was haphazardly assigned one of two treatments: chlorinated epoxy or amoxicillin paste. As a result of high failure rates on chlorine-treated corals, all sites treated after April 2019 used only amoxicillin paste. In total, 1320 corals were treated during initial site visits and an additional 865 were treated during subsequent monitoring events through October 2020 (total of 2185).

Because many corals and species had already perished at longdiseased sites, the abundance and diversity of corals that could be treated at each site varied (Figure 3). The density of treatable corals was notably lower at the Upper Keys and Sombrero sites ( 0.04 and 0.35 corals per $\mathrm{m}^{2}$ ) compared to offshore Looe Key and the three inshore sites ( 1.03 to 3.04 corals per $\mathrm{m}^{2}$ ). Across all sites, the three most commonly treated species were Orbicella faveolata (37\%), Montastraea cavernosa (21\%), and Colpophyllia natans (16\%). O. faveolata and M. cavernosa dominated offshore reef treatments, while inshore reef treatments were dominated by the brain corals $C$. natans and Pseudodiploria clivosa (at the Newfound Harbor site). The average maximum diameter of treated colonies was $115 \mathrm{~cm}( \pm 84 \mathrm{SD})$.
Each selected coral was tagged and mapped for future identification. Corals were identified to species, and 1" masonry nails were placed at each active lesion. Photographs of the colony and each lesion were taken before and after treatments.

Chlorinated epoxy was mixed following methodology formerly used on black band disease on Pacific reefs (Aeby et al., 2015). Before entering the water, chlorine powder (78\% calcium hypochlorite) was folded by hand into Part A of SplashZone two-part epoxy in a 3:10 by volume ratio. Once stationed at a selected coral, divers would hand-mix the chlorinated Part A with the non-chlorinated Part B and apply the mixture directly to all active disease margins. Additionally, an underwater angle-grinder was used to create a trenched disease break approximately $5 \mathrm{~cm}$ from each active disease lesion. Disease breaks were approximately $1 \mathrm{~cm}$ wide and $1 \mathrm{~cm}$ deep. Each disease break was also packed with the chlorinated epoxy mixture.

The amoxicillin paste was created by hand-mixing amoxicillin trihydrate (98.1\% purity, sourced from Phytotechnology Laboratories) into a specially formulated silicone-based paste termed Base2b. The proprietary base (CoreRx/Ocean Alchemists) includes polymers to mimic coral mucus consistency and releases amoxicillin over a 3-day time period. The Base $2 \mathrm{~b}$ and amoxicillin were hand-mixed no more than $36 \mathrm{~h}$ before application to the corals and packed into $60 \mathrm{cc}$ catheter-tip syringes. At the corals selected for treatment, divers would syringe the product onto active disease lesions and then press it into the bare skeleton for adhesion. The product made a band approximately $1 \mathrm{~cm}$ in width, with about half overlaying live tissue and the other half anchoring to the skeleton.

Colonies were revisited over the course of up to 710 days for monitoring and treatment of new lesions as needed. The goal for monitoring was for each coral to be revisited at 1 month, and then every 2 months thereafter. Actual monitoring varied slightly, particularly at Looe Key which was initially split into two regions for monitoring every other month. During each monitoring event, photographs were taken of the whole colony and of each current and previously treated disease lesion. Photographs from each monitoring event were used to assess whether the treatments had been effective (defined as the active lesion halting at the treatment line) or ineffective (defined as the lesion continuing past the treatment line across the colony) (Figure 4). For lesions with chlorinated epoxy applications, ineffective treatments were defined as those that had passed both the margin treatment and the disease break. 


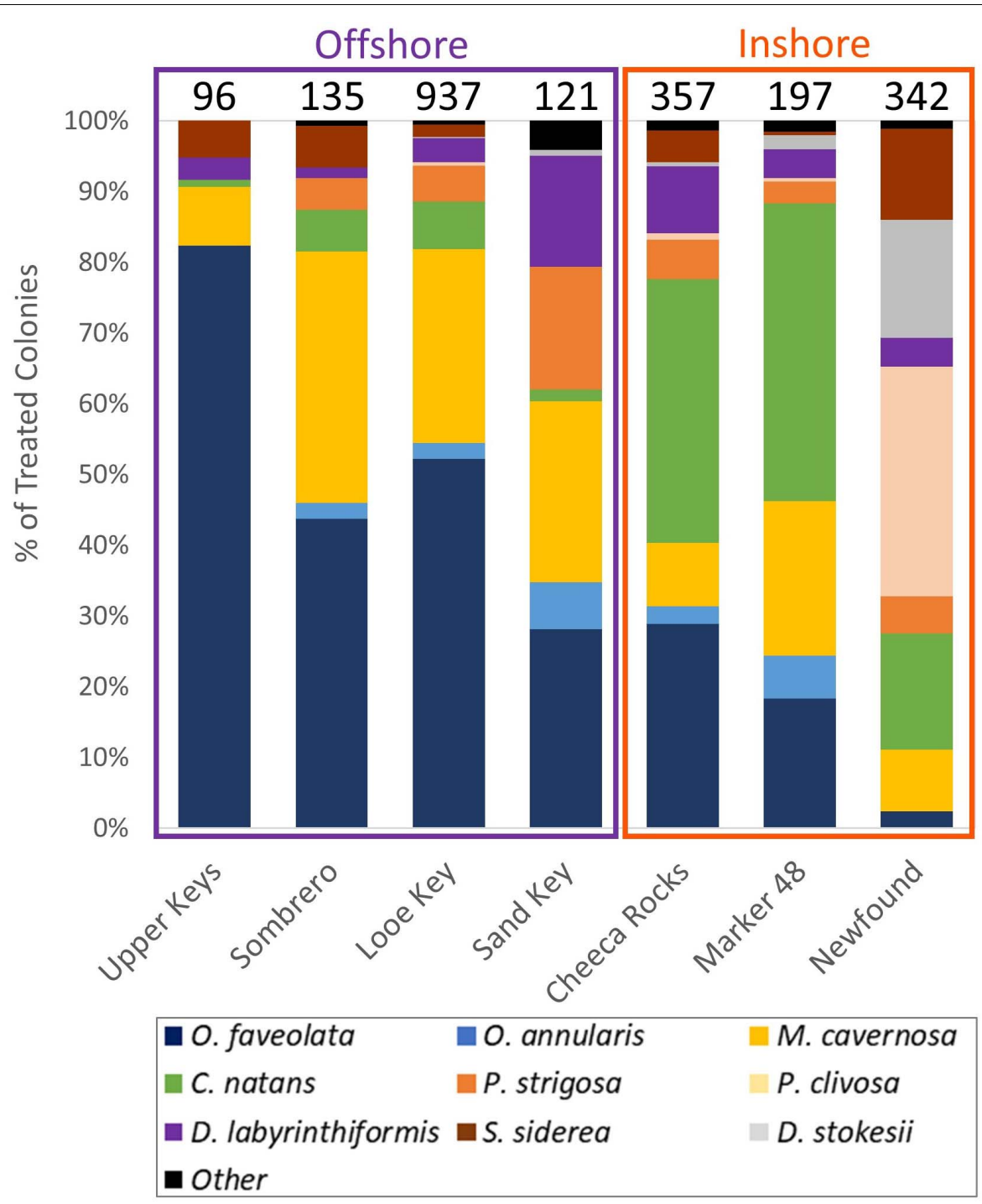

FIGURE 3 | Species composition of corals treated at FKNMS sites. Top numbers indicate the total number of treated corals at each site.

Corals that had active disease lesions during subsequent monitoring events received additional treatments on new lesions as needed. However, there were some instances where this did not occur. In the upper Keys, Sombrero, and some parts of Looe Key, colonies monitored 1 month after the initial treatment did not receive additional treatments at that time. Additionally, a small number of corals across all sites displayed active disease during monitoring, but no longer qualified as priority corals and were not treated again. By April 2019, it was clear that chlorine treatments were largely unsuccessful, and follow-up treatments were done with amoxicillin paste regardless of whether the coral was initially treated with amoxicillin or chlorine. The exception was 38 corals at Looe Key that were initially treated with chlorinated epoxy and were re-treated with chlorinated epoxy on active disease areas during the 2-month monitoring; these were all treated during subsequent monitoring events with amoxicillin if needed. During each monitoring event, every coral was categorized as either (1) dead, (2) active lesions - untreated, (3) treated, or (4) no active disease (NAD).

\section{Analyses}

\section{Lesion-Level Effectiveness}

The effectiveness of amoxicillin and chlorine treatments at halting disease lesion progression for 3 months post-treatment was evaluated using a mixed effects logistic regression analysis. The binary response variable represented the effectiveness (1) or ineffectiveness (0) of treatment on 2,379 individual lesions present on 725 colonies from five species (Colpophyllia natans, Pseudodiploria strigosa, Diploria labyrinthiformis, Montastraea cavernosa, and Orbicella faveolata). Treated lesions were monitored periodically (Supplementary Figure 1A) during the initial 140-day time frame in the upper Keys (Carysfort South, Key Largo Dry Rocks, Grecian Rocks), middle Keys (Sombrero Reef), and lower Keys (Looe Key). If a lesion required 


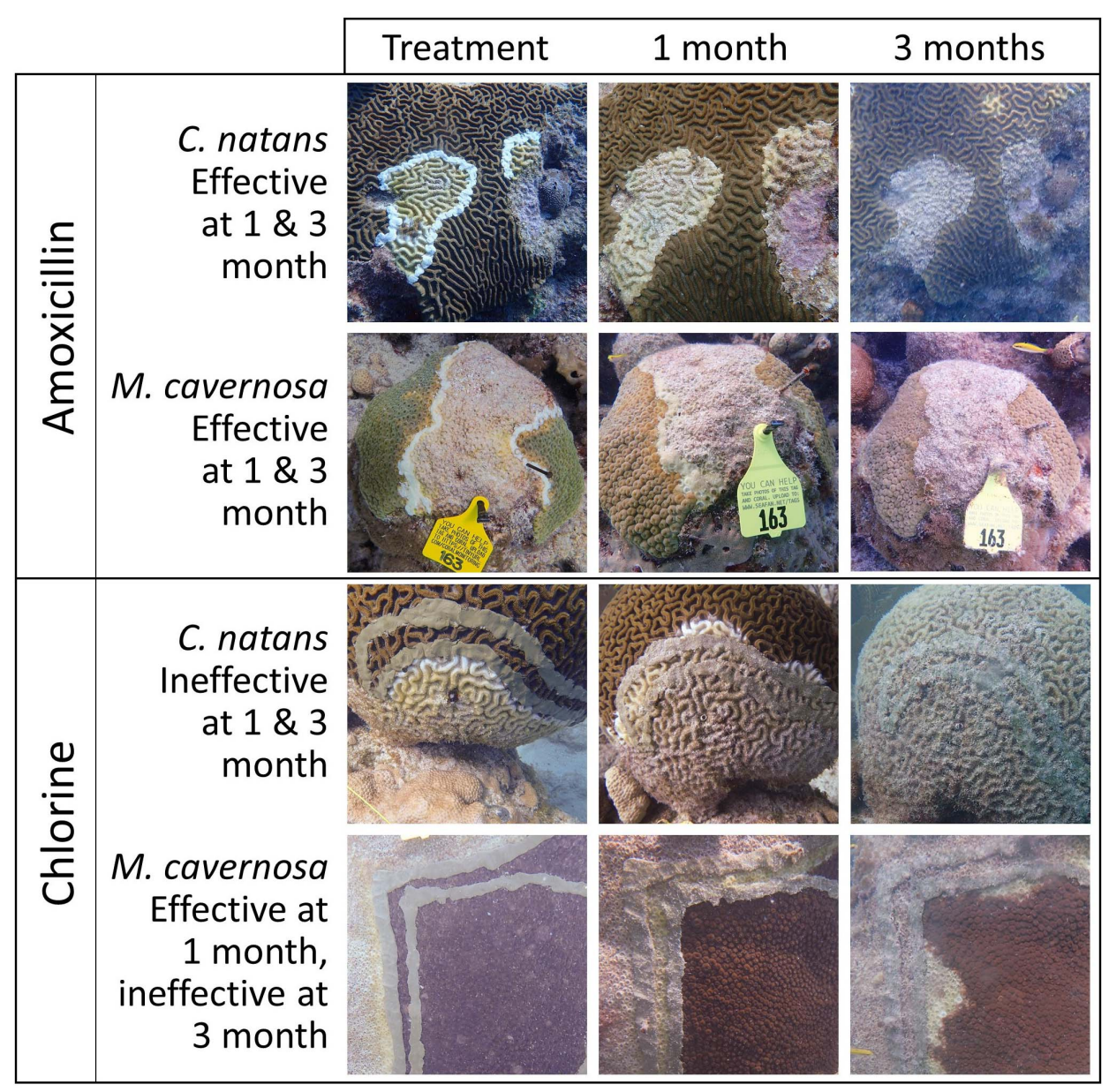

FIGURE 4 | Time series photos showing effective amoxicillin treatments and ineffective chlorinated treatments on two coral species: Colpophyllia natans (CNAT) and Montastraea cavernosa (MCAV). Disease lesions were defined as ineffective only once they had crossed both the margin and disease break chlorinated epoxy treatments.

retreatment, it was considered ineffective for that and future monitoring events.

We fit a candidate set of eight logistic regression models, each of which included a different combination of the predictors and two-way interaction terms (treatment type; region; species; number of days since treatment; number of days since treatment $\times$ treatment type, region $\times$ treatment type, and species $\times$ treatment type). To account for non-independence of repeated observations of lesions on the same colonies, we included a random intercept associated with unique corals (Gellman and Hill, 2007). We ranked the plausibility of each candidate model using Akaike's Information Criterion [AIC; Akaike (1973)] with a small-sample bias adjustment [AICc; Hurvich and Tsai (1989)]. To quantify the relative support of each candidate model, we calculated Akaike weights (w) that range from zero to one, with the best-approximating model having the highest weight (Burnham and Anderson, 2002). The ratio of Akaike weights for two candidate models can be used to assess the degree of evidence for one model over another; for example, a model with an Akaike weight of 0.9 is 10 times more likely to be the best-approximating model compared to a model with an Akaike weight of 0.09 . We based all inferences on the bestapproximating model i.e., the model with the lowest AICc score. Following model-fitting and model selection, we assessed goodness-of-fit for each model in the candidate set using a residual-based, simulation approach implemented in the $\mathrm{R}$ package "DHARMa" (Hartig, 2019). Additionally, we assessed the performance for each model by calculating an area under the receiving operator characteristic curve (AUC) statistic. AUC values $>0.5$ indicate that a model predicts a categorical outcome, on average, better than random chance alone. All statistical analyses were conducted in R v.4.0.3 (R Development Core Team, 2013) using the packages "glmmTMB" [model fitting: logistic regression with logit link function; Brooks et al. (2017)] and "ROCR" [predictive performance; Sing et al. (2005)].

Following model fitting, we implemented post hoc contrasts (Tukey-adjusted pairwise comparisons with a 95\% familywise confidence level) in $\mathrm{R}$ using the "emmeans" package (Lenth, 2018) to provide a more detailed assessment of differences in treatment effectiveness among species and regions. 


\section{Colony Health Status}

The health status of amoxicillin-treated corals was evaluated using mixed effects logistic regression to estimate the probability of a coral within the treatment regime being observed with no active disease (NAD) during monitoring. A total of 1,664 coral colonies representing eight species (C. natans, D. labyrinthiformis, D. stokesii, M. cavernosa, O. annularis, $O$. faveolata, P. strigosa, and $S$. siderea) were visited a total of 9956 times ranging from 8 to 710 days after initial treatment (Supplementary Figure 1B). The binary response variable represented the absence (1) or presence (0) of disease. Here, the absence of disease was defined as instances where a colony previously afflicted by SCTLD no longer exhibited any evidence of active disease. Any colonies with active lesions or mortality were considered diseased. We fit a candidate set of eight mixed effects logistic regression models, each of which included a different combination of the predictor variables (region; habitat; species; number of days since treatment; and all two-way interactions between region, habitat, and species). As with the 3-month lesion treatment analysis, we accounted for nonindependence of repeated observations on the same colonies by including a random intercept associated with unique corals. We again ranked the plausibility of each candidate model using AICc and Akaike weights. Lastly, we based all inferences on the model with the lowest AICc score and assessed goodness of fit and predictive performance as described above for the 3-month lesion treatment effectiveness model.

Following model fitting, post hoc contrasts (Tukey-adjusted pairwise comparisons with a 95\% familywise confidence level) were again implemented in R using the "emmeans" package to provide a more detailed assessment of differences in long-term disease status among species, regions, and habitats.

\section{RESULTS}

\section{Lesion-Level Effectiveness}

The best-approximating mixed effects logistic regression model assessing the probability of successful lesion treatment included number of days since treatment, treatment type, region, species, number of days since treatment $\times$ treatment type, region $\times$ treatment type, and species $\times$ treatment type. Akaike weights indicated that this model was 10.1 times $(0.91 / 0.09)$ more plausible than the next-best approximating model, which was similar but excluded the region $\times$ treatment type interaction term. There was no support for the remaining six candidate models (Supplementary Table 1). The goodness of fit assessments based on scaled residuals indicated that all candidate logistic regression models provided an adequate fit to the data. Lastly, the AUC statistics for the eight candidate models ranged from 0.96 to 0.97 , indicating they were all capable of predicting the observed data well.

Across all species and regions, the probability of amoxicillin treatment effectiveness was high. At 109 days, predicted effectiveness exceeded 95\% among all tested species at Looe and the upper Keys. Effectiveness was slightly lower for D. labyrinthiformis and O. faveolata at Sombrero, but still exceeded 75\% (Figure 5). Across regions, amoxicillin treatments responded similarly, with the exception of corals at Sombrero, which did not respond to treatment as effectively as corals at Looe (Tables 2, 3). This regional pairwise comparison is significant $(p<0.0001)$, but the magnitude of differences was minor as effectiveness was still high at both sites. Based on the best approximating model across all regions and times within the 3-month analyses, all five species responded equally well to amoxicillin (Table 4).

In contrast to amoxicillin treatments, chlorinated epoxy treatments were ineffective (Figure 5). This chlorinate epoxy effectiveness was equally poor across all regions, and was significantly less effective than amoxicillin treatments across all regions $(p<0.001)$ (Tables 2, 3). Among species, the brain corals C. natans, D. labyrinthiformis, and P. strigosa had lower effectiveness rates than the boulder corals $M$. cavernosa and O. faveolata (Tables 2, 4). However, these summaries are across all times after treatment; while $M$. cavernosa and $O$. faveolata treatments did not fail as early as those of the brain corals, their rate of effectiveness 3 months after treatment was less than $20 \%$.

\section{Colony Health Status}

To assess the probability of a coral having no active disease (NAD) at up to 24 months after initial treatment and necessary touchups, eight mixed effects logistic regression models were considered for goodness of fit. The best fit model contained the following parameters: number of days since treatment, habitat (inshore or offshore), region (upper Keys, middle Keys, or lower Keys), species, a habitat $\times$ species interaction term, and a region $\times$ species interaction term. Akaike weights $(w)$ indicated that this model was 6.9, 8.6, and 11.5 times more plausible than the second, third, and fourth best-approximating models, respectively, and there was very little support for the remaining four candidate models (Supplementary Table 2). The goodness of fit assessments based on scaled residuals indicated that all candidate logistic regression models provided an adequate fit to the data. Lastly, the AUC statistics for the eight candidate models ranged from 0.86 to 0.87 , indicating they were capable of predicting the observed data reasonably well.

Parameter estimates from the best-approximating model indicated a positive relationship between the date after initial treatment and the probability of NAD (Table 5 and Figure 6). The most pronounced variable affecting this probability was habitat (inshore vs. offshore). After 24 months, the proportion of colonies with NAD exceeded $95 \%$ for most species at inshore sites. In contrast, several species had NAD rates of less than $80 \%$ at offshore sites. Of the eight compared species (C. natans, D. labyrinthiformis, D. stokesii, M. cavernosa, $O$. annularis, O. faveolata, $P$. strigosa, and S. siderea), all but $D$. stokesii and $O$. annularis had significantly higher NAD values at inshore sites than offshore sites (Table 6). Some speciesspecific variations in NAD rates were apparent within different geographies, with more differences occurring at offshore sites (Table 7). Orbicella faveolata performed more poorly (lower NAD values) than C. natans (offshore middle Keys, offshore upper Keys, inshore upper Keys), D. labyrinthiformis (offshore 


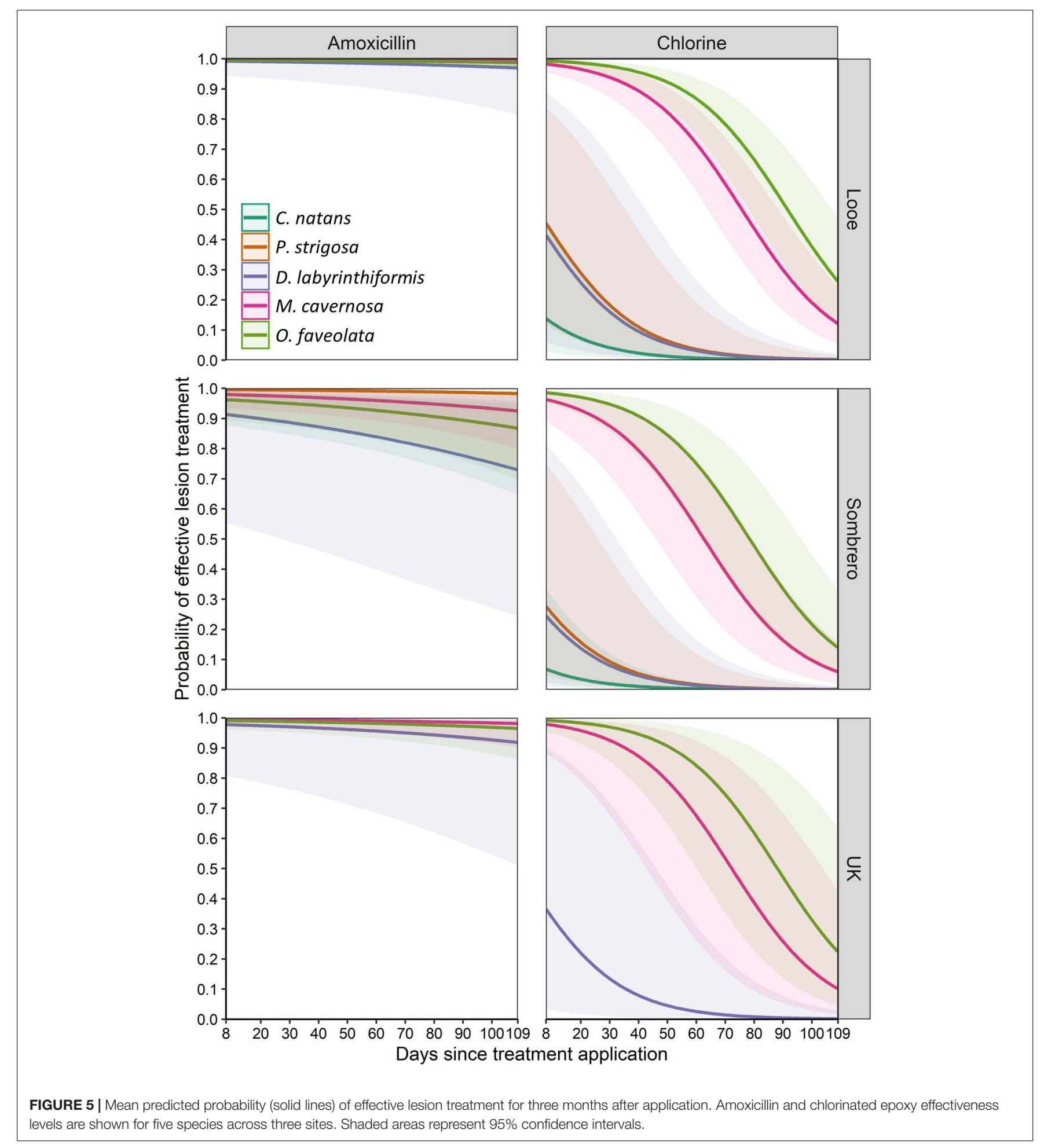

lower Keys), P. strigosa (inshore upper Keys), and $M$. cavernosa (offshore middle Keys). S. siderea also performed more poorly than $P$. strigosa (offshore lower Keys) and M. cavernosa (offshore lower Keys and offshore upper Keys). Colpophyllia natans performed more poorly than $M$. cavernosa in the offshore middle Keys.

\section{DISCUSSION}

Clear differences between treatment types were apparent in assessing effectiveness on SCTLD lesions. Chlorinated epoxy treatments on SCTLD lesions were highly ineffective, with corals of all species at all sites exhibiting high rates of failure 
TABLE 2 | Parameter estimates affecting the probability of halted disease progression up to 3 months after treatment.

\begin{tabular}{|c|c|c|c|c|c|c|}
\hline & Parameter & Estimate & SE & LCL & UCL & $p$-value \\
\hline \multicolumn{7}{|l|}{ Fixed effects } \\
\hline & Intercept & 6.458 & 0.960 & 4.576 & 8.340 & $<0.0001$ \\
\hline Treatment & Chlorine & -7.814 & 1.345 & -10.450 & -5.178 & $<0.0001$ \\
\hline Time & Days & -0.013 & 0.005 & -0.024 & -0.003 & 0.011 \\
\hline \multirow[t]{2}{*}{ Region } & Sombrero & -2.478 & 0.494 & -3.446 & -1.509 & $<0.0001$ \\
\hline & Upper Keys (UK) & -1.049 & 0.675 & -2.371 & 0.273 & 0.120 \\
\hline \multirow[t]{4}{*}{ Species } & D. labyrinthiformis (DLAB) & -1.521 & 1.253 & -3.977 & 0.936 & 0.225 \\
\hline & M. cavernosa (MCAV) & -0.007 & 0.907 & -1.785 & 1.771 & 0.994 \\
\hline & O. faveolata (OFAV) & -0.634 & 0.873 & -2.345 & 1.076 & 0.467 \\
\hline & P. strigosa (PSTR) & 1.510 & 1.683 & -1.788 & 4.808 & 0.370 \\
\hline Treatment $\times$ Time & Chlorine $\times$ Days & -0.046 & 0.008 & -0.061 & -0.031 & $<0.0001$ \\
\hline \multirow[t]{2}{*}{ Treatment $\times$ Region } & Chlorine $\times$ Sombrero & 1.698 & 0.575 & 0.570 & 2.826 & 0.003 \\
\hline & Chlorine $\times$ UK & 0.842 & 1.042 & -1.200 & 2.884 & 0.419 \\
\hline \multirow[t]{4}{*}{ Treatment $\times$ Species } & Chlorine $\times$ DLAB & 3.009 & 1.889 & -0.693 & 6.711 & 0.111 \\
\hline & Chlorine $\times$ MCAV & 5.875 & 1.321 & 3.286 & 8.464 & $<0.0001$ \\
\hline & Chlorine $\times$ OFAV & 7.444 & 1.353 & 4.793 & 10.095 & $<0.0001$ \\
\hline & Chlorine $\times$ PSTR & 0.139 & 2.052 & -3.883 & 4.161 & 0.946 \\
\hline \multicolumn{7}{|l|}{ Random effects } \\
\hline & Intercept (Coral ID) & 2.813 & & & & \\
\hline
\end{tabular}

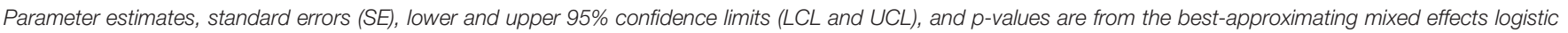

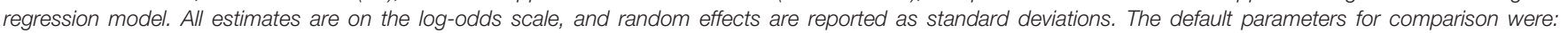
Treatment - Amoxicillin, Days - 0, Region - Looe Key, Species - Colpophyllia natans (CNAT).

TABLE 3 | Significant differences ( $p$-values) in modeled treatment effectiveness among treatment types (amoxicillin and chlorine) and regions (Looe: lower Keys, Sombrero: middle Keys, and UK: upper Keys).

\begin{tabular}{|c|c|c|c|c|c|c|c|}
\hline & & \multicolumn{3}{|c|}{ Amoxicillin } & \multicolumn{3}{|c|}{ Chlorine } \\
\hline & & Looe & Sombrero & UK & Looe & Sombrero & UK \\
\hline \multirow[t]{3}{*}{ Amoxicillin } & Looe & & $<0.0001$ & 0.629 & $<0.0001$ & $<0.0001$ & $<0.0001$ \\
\hline & Sombrero & $<0.0001$ & & 0.421 & $<0.0001$ & $<0.0001$ & $<0.0001$ \\
\hline & UK & 0.629 & 0.421 & & $<0.0001$ & $<0.0001$ & $<0.0001$ \\
\hline \multirow[t]{3}{*}{ Chlorine } & Looe & $<0.0001$ & $<0.0001$ & $<0.0001$ & & 0.626 & 1.000 \\
\hline & Sombrero & $<0.0001$ & $<0.0001$ & $<0.0001$ & 0.626 & & 0.990 \\
\hline & UK & $<0.0001$ & $<0.0001$ & $<0.0001$ & 1.000 & 0.990 & \\
\hline
\end{tabular}

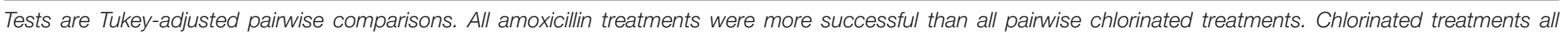
performed equally poorly. Among amoxicillin treatments, Looe treatments were slightly but significantly more effective than those at Sombrero.

within the first 3 months. Effectiveness rates decreased with time and varied by species, largely based on the speciesspecific rate of lesion progression. On brain corals ( $P$. strigosa, C. natans, and D. labyrinthiformis), lesions progressed quickly across the colonies, and by the first monitoring period, lesions had usually progressed past both the margin treatment and the disease break treatment, constituting a fully ineffective lesion treatment. In contrast, on species with slower lesion progression (O. faveolata and $M$. cavernosa) lesions had generally only crossed the chlorinated disease margin treatment 1 month after treatment; during later observations, the continually progressing lesion had also crossed the disease break and was scored as ineffective (Figure 4). Thus, the seemingly high rates of chlorine treatment effectiveness on some species immediately following treatment were not representative of treatments that halted disease progression.
In contrast, amoxicillin treatments were highly effective, quickly halting lesion progression on all species at all sites. There were no differences in amoxicillin effectiveness on treated lesions among species, indicating this methodology is suitable and effective for the suite of SCTLD-affected species. Though sample sizes for other coral species were too small for inclusion in the logistic models, a total of 16 species have been treated with the amoxicillin paste with similar success rates. In comparing treatments with placebos, Neely et al. (2020) confirmed amoxicillin rather than the application paste as the active ingredient. As a result of these comparative studies, chlorinated epoxy treatments were discontinued in Florida and are not recommended for SCTLD-affected corals.

Tracking of long-term colony health confirmed that while SCTLD lesions can be halted by amoxicillin treatments, additional distinct lesions may subsequently appear on treated 
TABLE 4 | Significant differences ( $p$-values) in modeled treatment effectiveness among species under two different treatment types (amoxicillin and chlorinated epoxy).

\begin{tabular}{lccccc}
\hline \multicolumn{5}{c}{ Amoxicillin treatments } \\
\hline & CNAT & DLAB & PSTR & MCAV & OFAV \\
\hline CNAT & & 0.744 & 0.898 & 1.000 & 0.950 \\
DLAB & 0.744 & & 0.411 & 0.572 & 0.895 \\
PSTR & 0.898 & 0.411 & & 0.854 & 0.603 \\
MCAV & 1.000 & 0.572 & 0.854 & & 0.651 \\
OFAV & 0.950 & 0.895 & 0.603 & 0.651 & \\
\hline & & Chlorinated epoxy treatments & \\
\hline & CNAT & DLAB & PSTR & MCAV & OFAV \\
\hline CNAT & & 0.838 & 0.639 & $<0.0001$ & $<0.0001$ \\
DLAB & 0.838 & & 1.000 & 0.007 & $<0.001$ \\
PSTR & 0.639 & 1.000 & & $<0.001$ & $<0.001$ \\
\hline MCAV & $<0.0001$ & 0.007 & $<0.001$ & & 0.227 \\
\hline OFAV & $<0.0001$ & $<0.001$ & $<0.001$ & 0.227 & \\
\hline
\end{tabular}

Tests are Tukey-adjusted pairwise comparisons. There was no difference among modeled success rates of amoxicillin treatments among species. Among chlorinated epoxy treatments, Montastraea cavernosa and Orbicella faveolata performed significantly better, but these results were summed over the 3-month period and do not reflect results toward the end of that time period.

colonies. These lesions may be the result of systemic infection or of reinfection from the environment. Much of the histological and microbiome studies on SCTLD-affected corals remains inconclusive as to whether SCTLD is systemic within a colony or localized to the visible infection site. For example, gastrodermal necrosis was found in $87 \%$ of visually diseased histological samples as well as in $11 \%$ of apparently healthy areas of tissue (Landsberg et al., 2020). And microbial communities on apparently healthy tissue of affected colonies are sometimes similar to those of unaffected colonies while other times more similar to those at active lesions (Meyer et al., 2019; Rosales et al., 2020; Thome et al., 2021). It has also been suggested that the bacteria seen in microbiome studies are purely opportunistic, capitalizing on other underlying health issues (Landsberg et al., 2020). Whether new lesions are caused by independent infection events or an underlying systemic condition has important implications for long-term colony health and disease management and certainly warrants future research.

Though new lesions could appear on previously treated colonies, corals that received regular monitoring and lesion touch-ups as needed progressively exhibited improved health (no active lesions) over time. Possible mechanisms by which initial and follow-up treatments as necessary could contribute to this include:

1. Reducing the potentially systemic infection within colonies, sometimes through multiple treatments, resulting in decreased lesions development.

2. Reducing opportunistic harmful bacteria on a colony that lead to rapid tissue loss, even if bacteria are not the underlying cause of SCTLD.
3. Reducing the pathogen load of either disease-inducing or opportunistic bacteria across the site as a whole through multiple visitations and treatments, thus minimizing new infections and lesions across all colonies.

The mechanism behind treatments leading to healthy colonies is recommended as a topic for further research. In particular, why some colonies do not show signs of SCTLD after a single treatment while others continually exhibit new lesions is relevant for questions of resilience and assisted reproduction. The impact of treatments in reducing pathogen load and protecting the surrounding non-infected colonies is also unknown and of importance for effective SCTLD management.

For the purposes of terminology, we will refer to the appearance of a new distinct lesion as a "reinfection," though as acknowledged above, alternate hypotheses suggest it may be a result of systemic influences. The colony-level assessment models show that the probability of reinfection (i.e., the inverse of the probability of NAD) was not the same across all species. In particular, O. faveolata and S. siderea were more likely than other species to develop new lesions, particularly at offshore sites. One possible explanation is that the particularly large size of the $O$. faveolata colonies in relation to the other species provides more surface area for new infection events. However, S. siderea were comparable in size to other species, and also showed high reinfection rates. We suggest that somehow these species are physiologically more inclined toward reinfection. Considering that $O$. faveolata is the most important reef builder remaining on offshore Florida Keys reefs, and that $S$. siderea is the most abundant species on Florida Keys reefs, determining why these species do not perform as well as others following treatment is an important research question.

Almost all treated species showed significantly better longterm response rates at inshore reefs compared to offshore reefs. We here propose four hypotheses for this, which are recommended avenues of future research.

1. Bleaching at inshore reefs halted disease progression annually. During the summers of 2019 and 2020, severe paling and bleaching was seen on most individuals at the inshore sites, but not on the offshore sites. This paling/bleaching coincided with an almost complete cessation of active disease. This correlation between zooxanthellae loss and SCTLD lesions has also been observed at other Florida sites (Sharp et al., 2020) and in the United States Virgin Islands (Meiling et al., 2020). These inshore bleaching events may have reduced or eliminated the reef pathogen load, either superseding or working in collaboration with our intervention efforts, to rapidly diminish the possibility of subsequent new infections. Meiling et al. (2020) suggest that disease treatment efforts could be made more efficient by working during and immediately following such bleaching events; we suggest that year-round intervention even in areas likely to experience regular bleaching is important in order to keep colonies alive through times when disease is more likely to be abundant. 
TABLE 5 | Parameter estimates affecting the probability of a colony within the monitoring and touch-up regime being without disease up to 24 months after initial treatment.

\begin{tabular}{|c|c|c|c|c|c|c|}
\hline & Parameter & Estimate & SE & LCL & UCL & $p$-value \\
\hline \multicolumn{7}{|l|}{ Fixed effects } \\
\hline & Intercept & 1.143 & 0.210 & 0.732 & 1.554 & $<0.0001$ \\
\hline & Days & 0.003 & 0.000 & 0.002 & 0.004 & $<0.0001$ \\
\hline Habitat & Offshore & -1.423 & 0.286 & -1.983 & -0.863 & $<0.0001$ \\
\hline \multirow[t]{7}{*}{ Species } & D. labyrinthiformis (DLAB) & 0.295 & 0.462 & -0.609 & 1.200 & 0.52 \\
\hline & D. stokesii (DSTO) & -0.372 & 0.285 & -0.932 & 0.187 & 0.19 \\
\hline & M. cavernosa (MCAV) & -0.066 & 0.307 & -0.667 & 0.535 & 0.83 \\
\hline & O. annularis (OANN) & 0.149 & 0.960 & -1.734 & 2.031 & 0.88 \\
\hline & O. faveolata (OFAV) & -0.114 & 0.289 & -0.680 & 0.451 & 0.69 \\
\hline & P. strigosa (PSTR) & 1.012 & 0.462 & 0.106 & 1.918 & 0.03 \\
\hline & S. siderea (SSID) & 0.107 & 0.308 & -0.496 & 0.710 & 0.73 \\
\hline \multirow[t]{2}{*}{ Region } & Middle Keys (MK) & -0.713 & 0.270 & -1.243 & -0.182 & 0.01 \\
\hline & Upper Keys (UK) & 0.492 & 0.265 & -0.028 & 1.011 & 0.06 \\
\hline \multirow[t]{7}{*}{ Habitat $\times$ Species } & Offshore $\times$ DLAB & 0.068 & 0.538 & -0.986 & 1.123 & 0.90 \\
\hline & Offshore $\times$ DSTO & -0.530 & 1.142 & -2.767 & 1.708 & 0.64 \\
\hline & Offshore $\times$ MCAV & 0.796 & 0.368 & 0.076 & 1.517 & 0.03 \\
\hline & Offshore $\times$ OANN & -0.019 & 0.938 & -1.858 & 1.820 & 0.98 \\
\hline & Offshore $\times$ OFAV & -0.365 & 0.344 & -1.039 & 0.310 & 0.29 \\
\hline & Offshore $\times$ PSTR & -0.180 & 0.542 & -1.243 & 0.883 & 0.74 \\
\hline & Offshore $\times$ SSID & -0.832 & 0.522 & -1.856 & 0.192 & 0.11 \\
\hline \multirow[t]{14}{*}{ Region $\times$ Species } & $M K \times D L A B$ & -0.529 & 0.761 & -2.021 & 0.963 & 0.49 \\
\hline & MK $\times$ DSTO & 0.841 & 0.963 & -1.047 & 2.728 & 0.38 \\
\hline & $\mathrm{MK} \times \mathrm{MCAV}$ & 0.664 & 0.357 & -0.036 & 1.364 & 0.06 \\
\hline & $\mathrm{MK} \times \mathrm{OANN}$ & 0.403 & 0.850 & -1.262 & 2.069 & 0.63 \\
\hline & $\mathrm{MK} \times \mathrm{OFAV}$ & 0.728 & 0.334 & 0.074 & 1.382 & 0.03 \\
\hline & $\mathrm{MK} \times \mathrm{PSTR}$ & -1.499 & 0.752 & -2.972 & -0.025 & 0.05 \\
\hline & $\mathrm{MK} \times \mathrm{SSID}$ & 0.710 & 0.648 & -0.560 & 1.980 & 0.27 \\
\hline & $U K \times D L A B$ & -0.175 & 0.577 & -1.305 & 0.955 & 0.76 \\
\hline & UK $\times$ DSTO & 0.418 & 1.419 & -2.363 & 3.199 & 0.77 \\
\hline & UK $\times$ MCAV & 0.323 & 0.463 & -0.585 & 1.232 & 0.49 \\
\hline & UK $\times$ OANN & -1.134 & 1.116 & -3.321 & 1.052 & 0.31 \\
\hline & UK $\times$ OFAV & -0.730 & 0.320 & -1.357 & -0.102 & 0.02 \\
\hline & UK $\times$ PSTR & 0.083 & 0.767 & -1.420 & 1.587 & 0.91 \\
\hline & $\mathrm{UK} \times \mathrm{SSID}$ & -0.795 & 0.504 & -1.783 & 0.194 & 0.12 \\
\hline \multicolumn{7}{|l|}{ Random effects } \\
\hline & Intercept (Coral ID) & 1.024 & & & & \\
\hline
\end{tabular}

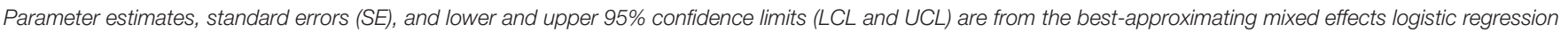

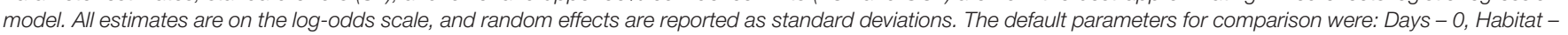
Inshore, Region - lower Keys, and Species - C. natans (CNAT).

2. Presence of more biodiverse and intact coral communities at inshore reefs confers resilience. The inshore reefs of the Florida Keys, including those treated here, have higher coral cover, larger average colony size, more evenly distributed population structures, greater species diversity, and higher coral growth rates than their offshore counterparts (Lirman and Fong, 2007; Ruzicka et al., 2013; Manzello et al., 2015; Vega-Rodriguez et al., 2015). Such biodiversity may have an impact on community disease susceptibility [see review in Rohr et al. (2020)]. Arguments for high biodiversity helping to protect individuals within an ecosystem include higher densities of non-susceptible hosts, lower numbers of susceptible hosts, and potential consumption of pathogens. In contrast, for a disease such as SCTLD which affects a large number of species, increased diversity and coral density may instead provide more hosts and worsen disease. Epidemiological models of SCTLD have indicated that more diverse sites may have higher SCTLD prevalence (Muller et al., 2020), while prevalence is independent of colony density (Sharp et al., 2020). Devastating SCTLD impacts on other regions with more intact reefs further suggest that this hypothesis of diverse and intact reef communities reducing SCTLD impact or improving treatment success is incorrect, but this may warrant future research. 


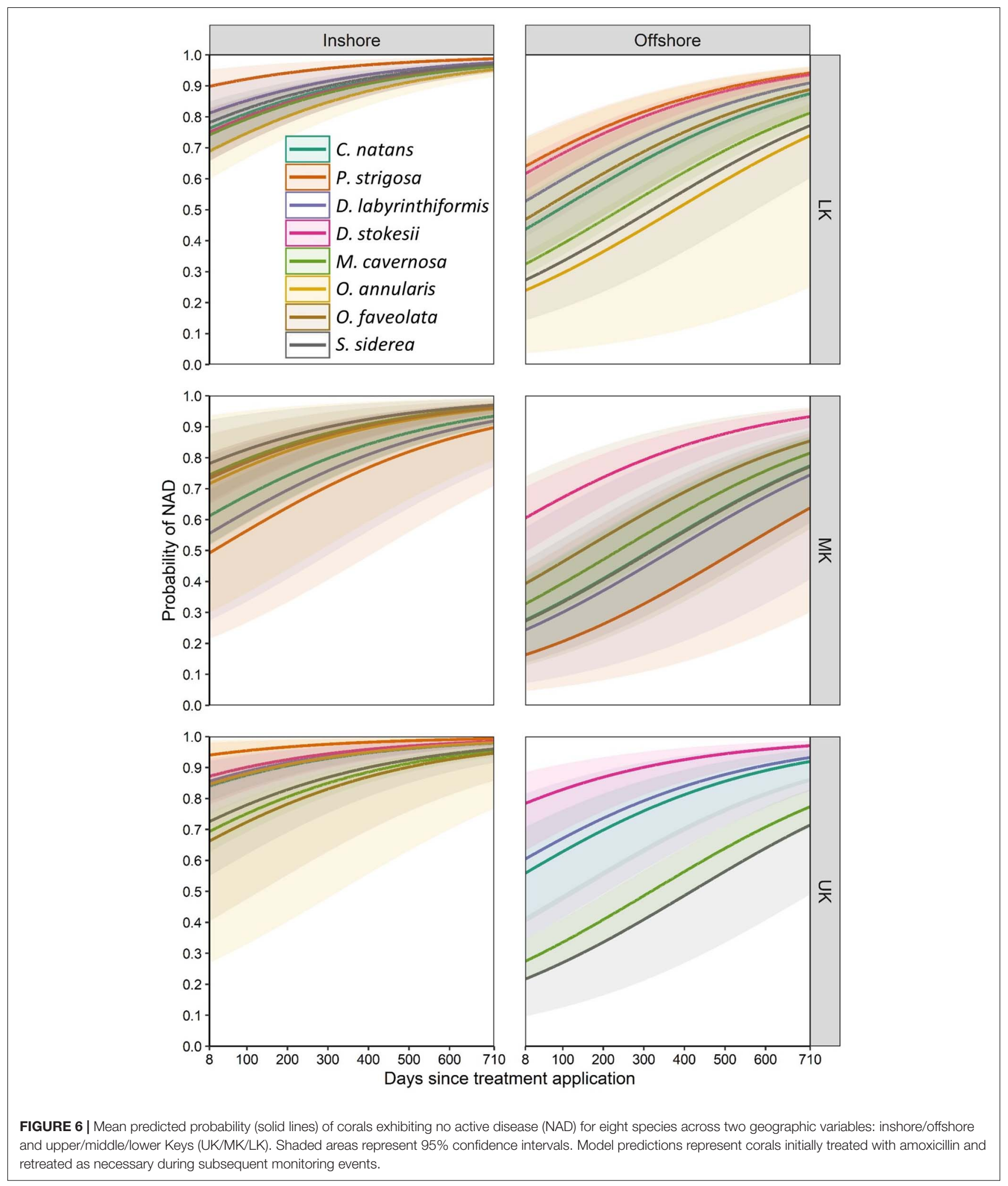

3. Presence of more resistant and resilient coral colonies at inshore reefs results in lower reinfection rates. Historic losses of non-Acroporid corals on offshore reefs are generally attributed to early (1989-1998) bleaching events (Somerfield et al., 2008), which did not cause the same levels of mortality on inshore reefs. One 
TABLE 6 | Tukey-adjusted pairwise comparisons (p-values) of "no active disease" (NAD) rates between inshore and offshore sites for eight coral species using the best approximating model.

\begin{tabular}{lccccc}
\hline Species & estimate & SE & df & t. ratio & p.value \\
\hline CNAT & 1.423 & 0.286 & 8920 & 4.981 & $<0.0001$ \\
DLAB & 1.355 & 0.457 & 8920 & 2.965 & 0.003 \\
DSTO & 1.953 & 1.106 & 8920 & 1.766 & 0.078 \\
MCAV & 0.627 & 0.232 & 8920 & 2.698 & 0.007 \\
OANN & 1.442 & 0.894 & 8920 & 1.612 & 0.107 \\
OFAV & 1.788 & 0.195 & 8920 & 9.19 & $<0.0001$ \\
PSTR & 1.603 & 0.462 & 8920 & 3.473 & 0.001 \\
SSID & 2.255 & 0.439 & 8920 & 5.137 & $<0.0001$ \\
\hline
\end{tabular}

For six species (Colpophyllia natans, Diploria labyrinthiformis, Montastraea cavernosa, Orbicella faveolata, Pseudodiploria strigosa, and Siderastrea siderea) amoxicillin-treated corals at inshore sites were more likely to be NAD than those at offshore sites.

hypothesis is that these inshore corals are stress-hardened as a result of higher temperature fluctuations, higher turbidity, and generally poorer water quality (Lirman and Fong, 2007), making individual colonies more resilient to bleaching-related mortality and perhaps to disease. Such resilience could present within the SCTLD treatment regime as an enhanced ability to resist reinfection events and/or to fight off a systemic infection with the help of treatment more effectively than offshore corals.

4. Isolation of inshore reefs may reduce reinfection potential. The reef tract off the Florida Keys consists of a largely continuous forereef punctuated by high-relief spur and groove formations. Though not densely populated with corals, this forereef presents a relatively continuous habitat for susceptible species that may act as continual reservoirs of SCTLD, capable of continually causing forereef reinfections even if pathogens are managed locally. In contrast, inshore sites are localized patch reefs separated from other coral habitat by sand or seagrass (Figure 7). Given sufficient time and the dynamic water movements of the region, all sites are likely to receive pathogen loads that result in infections. Those initial infections are likely to result in localized community spread within sites (Williams et al., 2021). During our initial treatment periods, more diseased colonies per unit area were present on inshore reefs than on offshore reefs. This would have suggested a higher localized pathogen load which would be expected to result in higher rates of reinfection at inshore reefs; however, the opposite pattern was observed. We suggest that localized intervention efforts were effective at reducing or even eliminating community spread within reefs, and that any subsequent reinfections on treated reefs resulted from transmission from surrounding untreated areas. On average, $6.5 \%( \pm 3.2 \mathrm{SD})$ of the habitat within $4 \mathrm{~km}$ of the offshore treatment sites was coral reef. In contrast, only $0.7 \%( \pm 0.2 \mathrm{SD})$ of the habitat within $4 \mathrm{~km}$ of the inshore treatment sites consisted of reef. We speculate that while both offshore and inshore reefs benefited from reduction of local pathogen loads as a result of treatment, the lower reinfection rates of inshore reefs were the result of their isolation and hence their decreased probability of reinfection from surrounding areas.

These hypotheses, or any combination of them, may render corals on inshore reefs less susceptible to reinfection and/or more responsive to treatment. Experimentation would be necessary to identify the relevant variables, and such research is recommended as it carries consequential management and biological implications. However, even without knowing the causal factors, we have identified that high-diversity, high-cover, isolated reefs that are susceptible to regular bleaching respond better to amoxicillin treatment than low-cover reefs surrounded by reef habitat that do not bleach. In the Florida Keys, these reefs further represent the highest potential for reproductive capacity based on proximity of conspecifics and abundance of SCTLD-susceptible species. Further, colony density at these sites results in much higher treatment and monitoring efficacy

TABLE 7 | Tukey-adjusted pairwise comparisons (p-values) of "no active disease" (NAD) rates among amoxicillin-treated colonies of eight coral species by region.

\begin{tabular}{|c|c|c|c|c|c|c|c|}
\hline & CNAT & DLAB & PSTR & DSTO & MCAV & OANN & OFAV \\
\hline \multicolumn{8}{|l|}{ DLAB } \\
\hline \multicolumn{8}{|l|}{ PSTR } \\
\hline \multicolumn{8}{|l|}{ DSTO } \\
\hline MCAV & O-MK (0.01) & & & & & & \\
\hline \multicolumn{8}{|l|}{ OANN } \\
\hline \multirow[t]{3}{*}{ OFAV } & O-MK (0.005) & O-LK (0.014) & I-UK (0.031) & & I-UK (0.050) & & \\
\hline & O-UK (0.024) & & & & & & \\
\hline & I-UK (0.005) & & & & & & \\
\hline \multirow[t]{2}{*}{ SSID } & & & O-LK (0.019) & & O-LK (0.014) & & \\
\hline & & & & & O-UK (0.001) & & \\
\hline
\end{tabular}

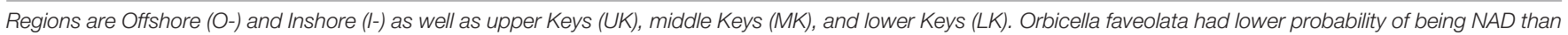

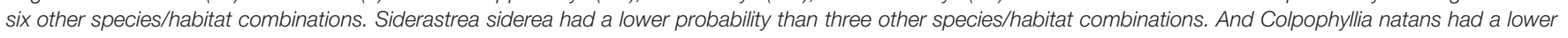
probability than one other species/habitat combination. 


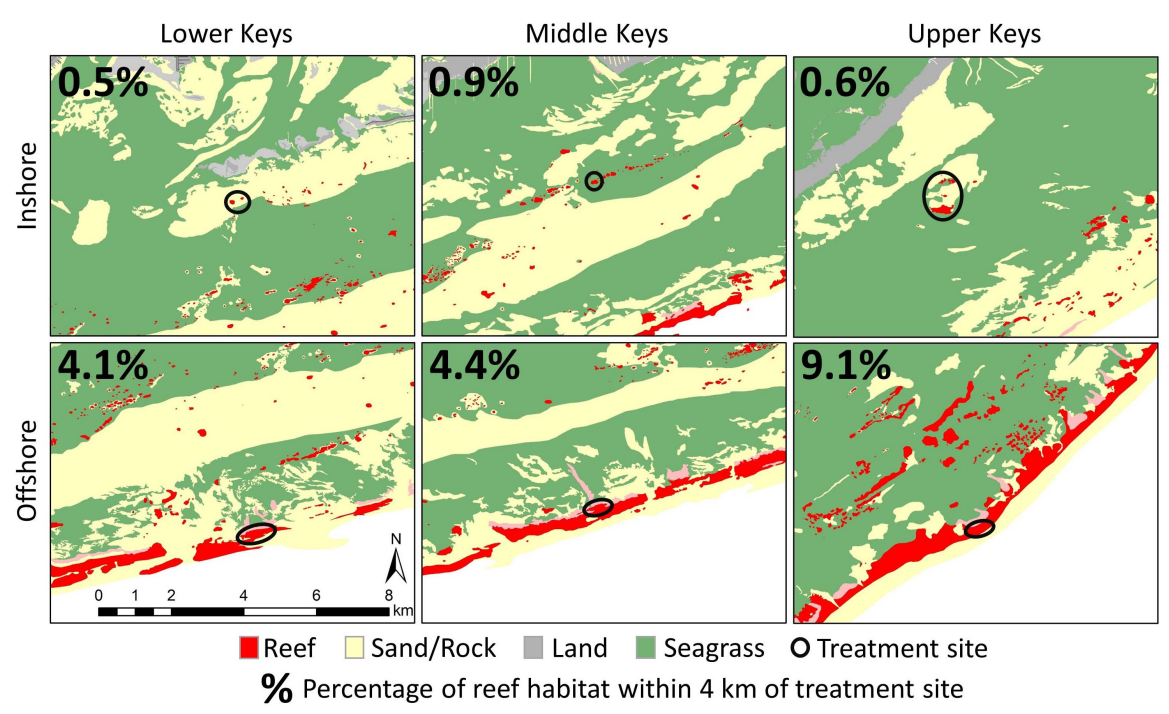

FIGURE 7 | Habitat maps surrounding six treatment sites (inshore and offshore within each region) indicating the relative isolation of inshore sites from surrounding reef environments compared to offshore sites. Red indicates reef environment, and black circles indicate treatment sites. All maps are to the same scale. Percentage values in each map indicate the percentage of habitat within a $4 \mathrm{~km}$ radius of each site that is reef habitat. Habitat classifications are derived from the Florida Unified Reef Map.
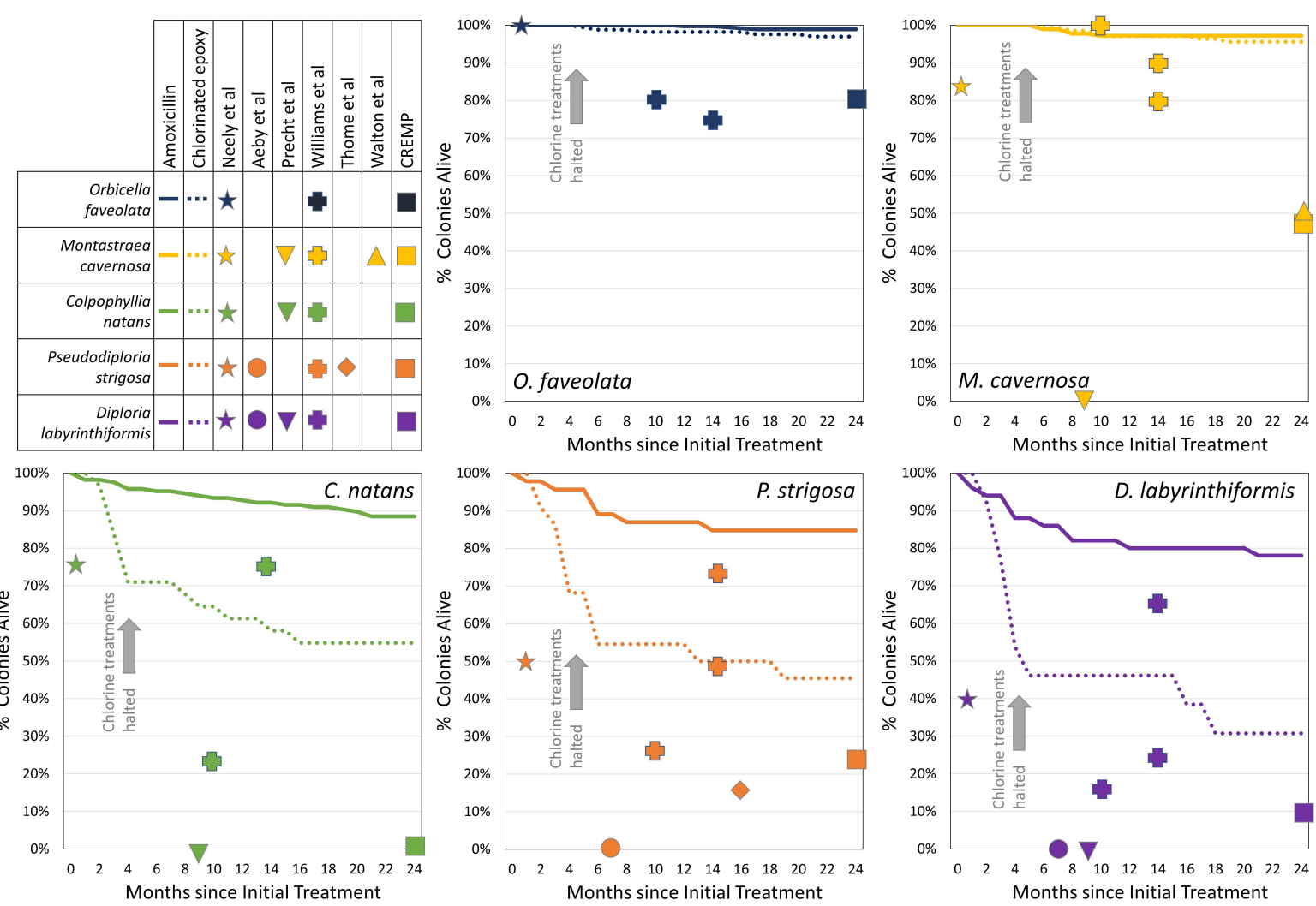

FIGURE 8 | Monthly survivorship curves for five coral species within the amoxicillin treatment regime (solid lines) and chlorinated epoxy treatment regime (dashed lines). Mortality of chlorinated epoxy-treated brain corals (Colpophyllia natans, Pseudodiploria strigosa, and Diploria labyrinthiformis) was rapid until all treatments were switched to amoxicillin 3 to 5 months after initial treatments. Species-specific mortality rates of corals at reported time points from other studies are indicated with shapes. Note that most other studies follow all corals within the population (including those which do not develop SCTLD), while the amoxicillin and chlorinated epoxy mortality curves follow only corals that were treated for SCTLD. 
compared to offshore sites that require considerable search time to find remaining live colonies. We recommend that intervention resources be focused primarily on these areas of high coral cover, high species diversity, better response to treatment, and high work efficiency.

Two years after initial treatments, mortality of SCTLDaffected colonies treated under the amoxicillin regims was only $5 \%$. One limitation of this study is the lack of non-treated controls; the decision to treat all SCTLD-affected corals was based on observations and studies throughout Florida and now through the Caribbean identifying extremely high mortality rates. Comparisons with non-treated corals monitored through these other studies highlight the value of such work (Figure 8).

1. Neely et al. (2020) tested controls and placebo treatments alongside amoxicillin treatments in the Florida Keys and identified control/placebo 1-month mortality rates of $60 \%$ on D. labyrinthiformis, $25 \%$ on C. natans, $50 \%$ on P. strigosa, $17 \%$ on M. cavernosa, and $0 \%$ on O. faveolata.

2. In work by Precht et al. (2016) on tagged SCTLD-affected colonies in Southeast Florida, mortality of SCTLD-afflicted colonies after 9 months was $100 \%$ across four species (9 Meandrina meandrites, 10 D. stokesii, 1 C. natans, $4 P$. strigosa, $8 M$. cavernosa, $1 P$. clivosa, and 2 Solenastrea. bournoni).

3. Thome et al. (2021) tagged 96 P. strigosa colonies on an SCTLD-affected reef in Mexico; within 306 days, mortality was greater than $84 \%$, with nearly half of the surviving colonies actively diseased at that point.

4. Aeby et al. (2019) tagged 13 actively diseased colonies in the Florida Keys (5 P. strigosa, 5 D. labyrinthiformis, 2 D. stokesii, and 1 Meandrina jacksonii); within 7 months, $100 \%$ of these were dead.

5. Williams et al. (2021) followed colonies at offshore and midchannel Florida Keys reefs through 14 months after SCTLD onset, and nearshore colonies through 10 months after SCTLD onset; mortality rates were $50-71 \%$ on D. stokesii, $33-83 \%$ on D. labyrinthiformis, 1-20\% on M. cavernosa, $0-$ $25 \%$ on O. faveolata, $25-77 \%$ on C. natans, and $27-75 \%$ on P. strigosa.

6. Though not tracking individual colonies, Walton et al. (2018) documented declines in density of $90 \%$ in D. stokesii, $95 \%$ in M. meandrites, $50 \%$ in M. cavernosa, and $32 \%$ in S. siderea over 2 years through the SCTLD outbreak.

7. Fixed survey sites in the upper Florida Keys documented substantial losses in colonies between pre-SCTLD years (average of 2014 - 2016) and post-SCTLD (2018): 18\% of Orbicella colonies, $52 \%$ of $M$. cavernosa, $78 \%$ of $P$. strigosa, $84 \%$ of D. stokesii, $91 \%$ of D. labyrinthiformis, and $100 \%$ of C. natans and M. meandrites (CREMP, unpublished data).

These known rates of exceptionally high mortality as a result of SCTLD infection highlight the importance of in-water treatment if in situ colonies are to be saved. These colonies represent centuries of growth highlighting a track record of hardiness against stressors. The habitat, reproductive output, and ecosystem services they provide are essential for reefs, even those undergoing restoration efforts. The effectiveness of amoxicillin treatments in halting SCTLD lesions and the long-term reduction in diseased colonies at sites that are regularly monitored and treated as needed identifies the use of this in-water intervention on SCTLD-affected sites as a viable method for saving corals and coral diversity in the presence of this unprecedented disease.

\section{CONCLUSION}

Corals affected by SCTLD were treated using two experimental methods to halt disease lesions: chlorinated epoxy and an amoxicillin paste. Logistic regression models from posttreatment monitoring data identified amoxicillin treatments as effective across all species; in contrast, chlorinated epoxy treatments failed across all species, with failure rates more rapid on species with faster lesion progression rates. Corals that were initially treated and then revisited approximately every 2 months for treatments on new lesions as needed showed long-term improvements in health, with nearly 95\% of treated corals exhibiting no signs of disease after 2 years. Speciesspecific comparisons in long-term health identified some species (particularly O. faveolata) as more susceptible to reinfections than others. Geographic comparisons showed that treated corals on inshore reefs had better long-term prognoses than those on offshore reefs. Hypotheses as to why inshore reefs respond better include: summer inshore bleaching events may reduce pathogen load, isolation from other reefs may limit reinfections, and stress-hardening or benefits of biodiversity may enhance colony resilience. The short- and long-term effectiveness of amoxicillin treatments provides an effective tool for preventing mortality of corals affected by SCTLD.

\section{DATA AVAILABILITY STATEMENT}

The raw data supporting the conclusions of this article will be made available by the authors, without undue reservation.

\section{AUTHOR CONTRIBUTIONS}

KN secured funding, conceived the data collection design, and wrote the manuscript with assistance from CS. CS conceived the model design and conducted statistical assessments. KN, KM, $\mathrm{EH}$, and $\mathrm{MD}$ conducted data collection and prepared data for analysis. KN and CS made the tables and figures. All authors edited and approved the manuscript.

\section{FUNDING}

Funding for these activities was provided by the Florida Department of Environmental Protection's Office of Resilience and Coastal Protection (Awards B373E8, B54DC0, and B77D91 to $\mathrm{KN}$ ). 


\section{ACKNOWLEDGMENTS}

This work was conducted under Florida Keys National Marine Sanctuary permits FKNMS-2019-115 and FKNMS2020-077. Application of antibiotics was authorized by the US Food and Drug Administration's Office of Minor Use and Minor Species (FDA-OMUMS). We are grateful for the assistance provided by Force Blue during the initial treatment applications (see further

\section{REFERENCES}

Abbott, R. C., Osorio, J. E., Bunck, C. M., and Rocke, T. E. (2012). Sylvatic plague vaccine: a new tool for conservation of threatened and endangered species? EcoHealth 9, 243-250. doi: 10.1007/s10393-012-0783-5

Aeby, G., Ushijima, B., Campbell, J. E., Jones, S., Williams, G., Meyer, J. L., et al. (2019). Pathogenesis of a tissue loss disease affecting multiple species of corals along the Florida Reef Tract. Front. Mar. Sci. 6:678. doi: 10.3389/fmars.2019. 00678

Aeby, G. S., Work, T. M., Runyon, C. M., Shore-Maggio, A., Ushijima, B., Videau, P., et al. (2015). First record of black band disease in the hawaiian archipelago: response, outbreak status, virulence, and a method of treatment. PLoS One 10:e0120853. doi: 10.1371/journal.pone.0120853

Akaike, H. (1973). "Information theory and an extension of the maximum likelihood principle," in Proceedings of the 2nd Int. Symp. on Inf. Theory, eds B. Petrov and F. Csaki (Budapest: Akademiai Kiado), 267-281.

Alvarez-Filip, L., Estrada-Saldívar, N., Pérez-Cervantes, E., Molina-Hernández, A., and González-Barrios, F. J. (2019). A rapid spread of the stony coral tissue loss disease outbreak in the Mexican Caribbean. PeerJ 7:e8069. doi: 10.7717/peerj. 8069

Aronson, R. B., and Precht, W. F. (2001). White-band disease and the changing face of Caribbean coral reefs. Hydrobiologia 460, 25-38. doi: 10.1007/978-94017-3284-0_2

Atad, I., Zvuloni, A., Loya, Y., and Rosenberg, E. (2012). Phage therapy of the white plague-like disease of Favia favus in the Red Sea. Coral Reefs 31, 665-670. doi: 10.1007/s00338-012-0900-5

Bosch, J., Sanchez-Tomé, E., Fernández-Loras, A., Oliver, J. A., Fisher, M. C., and Garner, T. W. (2015). Successful elimination of a lethal wildlife infectious disease in nature. Biol. Lett. 11:20150874. doi: 10.1098/rsbl.2015.0874

Boyett, H. V., Bourne, D. G., and Willis, B. L. (2007). Elevated temperature and light enhance progression and spread of black band disease on staghorn corals of the Great Barrier Reef. Mar. Biol. 151, 1711-1720. doi: 10.1007/s00227-006-0603-y

Brooks, M. E., Kristensen, K., Van Benthem, K. J., Magnusson, A., Berg, C. W., Nielsen, A., et al. (2017). glmmTMB balances speed and flexibility among packages for zero-inflated generalized linear mixed modeling. $R J .9,378-400$. doi: 10.32614/rj-2017-066

Bruckner, A. W. (2016). "History of coral disease research," in Diseases of Coral, 1st Edn, eds C. M. Woodley, C. A. Downs, A. W. Bruckner, J. W. Porter, and S. B. Galloway (Hoboken, NJ: John Wiley \& Sons), 52-84. doi: 10.1002/ 9781118828502.ch5

Burnham, K. P., and Anderson, D. R. (2002). "A practical information-theoretic approach," in Model Selection and Multimodel Inference, eds K. P. Burnham and D. R. Anderson (Cham: Springer).

Cervino, J. M., Hayes, R., Polson, S., Polson, S. C., Goreau, T., Martinez, R., et al. (2004). Relationship of vibrio species infection and elevated temperatures to yellow blotch/band disease in Caribbean Corals. Appl. Environ. Microbiol. 70, 6855-6864. doi: 10.1128/aem.70.11.6855-6864.2004

Chang, G. J. J., Davis, B. S., Stringfield, C., and Lutz, C. (2007). Prospective immunization of the endangered California condors (Gymnogyps californianus) protects this species from lethal West Nile virus infection. Vaccine 25, 23252330. doi: 10.1016/j.vaccine.2006.11.056

Cróquer, A., and Weil, E. (2009). Changes in Caribbean coral disease prevalence after the 2005 bleaching event. Dis. Aquat. Organ. 87, 33-43. doi: 10.3354/ dao02164 information here: https://forceblueteam.org/coral-diseaseintervention/).

\section{SUPPLEMENTARY MATERIAL}

The Supplementary Material for this article can be found online at: https://www.frontiersin.org/articles/10.3389/fmars. 2021.675349/full\#supplementary-material

Cróquer, A., Weil, E., Zubillaga, A. L., and Pauls, S. M. (2005). Impact of a white plague-II outbreak on a coral reef in the archipelago Los Roques National Park, Venezuela. Caribbean J. Sci. 41, 815-823.

Dalton, S., Godwin, S., Smith, S., and Pereg, L. (2010). Australian subtropical white syndrome: a transmissible, temperature-dependent coral disease. Mar. Freshw. Res. 61, 342-350. doi: 10.1071/mf09060

Efrony, R., Atad, I., and Rosenberg, E. (2009). Phage therapy of coral white plague disease: properties of phage BA3. Curr. Microbiol. 58, 139-145. doi: 10.1007/ s00284-008-9290-x

Efrony, R., Loya, Y., Bacharach, E., and Rosenberg, E. (2007). Phage therapy of coral disease. Coral Reefs 26, 7-13. doi: 10.1007/s00338-006-0170-1

Fettig, C. J., Gibson, K. E., Munson, A. S., and Negrón, J. F. (2013). Cultural practices for prevention and mitigation of mountain pine beetle infestations. For. Sci. 60, 450-463. doi: 10.5849/forsci.13-032

Florida Fish and Wildlife Research Institute (2014). Unified Florida Coral Reef Tract Map v1.2.

Gellman, A., and Hill, J. (2007). Data Analysis Using Regression and Multilevel/Hierarchical Models. Cambridge: Cambridge University Press.

Gil-Agudelo, D., Smith, G., Garzón-Ferreira, J., Weil, E., and Petersen, D. (2004). "Dark spots disease and yellow band disease, two poorly known coral diseases with high incidence in Caribbean reefs," in Coral Health and Disease, eds E. Rosenberg and Y. Loya (Berlin: Springer), 337-349. doi: 10.1007/978-3-66206414-6_19

Goltsman, M., Kruchenkova, E. P., and Macdonald, D. W. (1996). The Mednyi arctic foxes: treating a population imperilled by disease. Oryx 30, 251-258. doi: $10.1017 /$ s0030605300021748

Green, E. P., and Bruckner, A. W. (2000). The significance of coral disease epizootiology for coral reef conservation. Biol. Conserv. 96, 347-361. doi: 10.1016/s0006-3207(00)00073-2

Harrenstien, L. A., Munson, L., Ramsay, E. C., Lucash, C. F., Kania, S. A., and Potgieter, L. N. D. (1997). Antibody responses of red wolves to canine distemper virus and canine parvovirus vaccination. J. Wildl. Dis. 33, 600-605. doi: 10. 7589/0090-3558-33.3.600

Hartig, F. (2019). DHARMa: Residual Diagnostics for Hierarchical (MultiLevel/Mixed) Regression Models. R package version 0.2 .

Haydon, D. T., Randall, D. A., Matthews, L., Knobel, D. L., Tallents, L. A., Gravenor, M. B., et al. (2006). Low-coverage vaccination strategies for the conservation of endangered species. Nature 443, 692-695. doi: 10.1038/nature 05177

Heres, M. M., Farmer, B. H., Elmer, F., and Hertler, H. (2021). Ecological consequences of stony coral tissue loss disease in the Turks and Caicos Islands. Coral Reefs 40, 609-624. doi: 10.1007/s00338-021-02071-4

Hudson, J. (2000). "First aid for massive corals infected with black band disease, Phormidium corallyticum: an underwater aspirator and post-treatment sealant to curtail reinfection," in Proceedings of the AAUS 20th Symposium Proceedings, Monterey, CA, 10-11.

Hurvich, C. M., and Tsai, C.-L. (1989). Regression and time series model selection in small samples. Biometrika 76, 297-307. doi: 10.1093/biomet/76.2.297

Kline, D. I., and Vollmer, S. V. (2011). White band disease (type I) of endangered caribbean acroporid corals is caused by pathogenic bacteria. Sci. Rep. 1, 1-5.

Landsberg, J. H., Kiryu, Y., Peters, E. C., Wilson, P. W., Perry, N., Waters, Y., et al. (2020). Stony coral tissue loss disease in Florida is associated with disruption of host-zooxanthellae physiology. Front. Mar. Sci. 7:576013. doi: 10.3389/fmars. 2020.576013 
Langwig, K. E., Voyles, J., Wilber, M., Frick, W., Murray, K., Bolker, B., et al. (2015). Context-dependent conservation responses to emerging wildlife diseases. Front. Ecol. Environ. 13:195-202.

Lapointe, B. E., Brewton, R. A., Herren, L. W., Porter, J. W., and Hu, C. (2019). Nitrogen enrichment, altered stoichiometry, and coral reef decline at Looe Key, Florida Keys, USA: a 3-decade study. Mar. Biol. 166:108.

Lenth, R. (2018). emmeans: Estimated Marginal Means, aka Least-Squares Means. $R$ package version 1.1 .

Lewis, C. L., Neely, K. L., Richardson, L. L., and Rodriguez-Lanetty, M. (2017). Temporal dynamics of black band disease affecting pillar coral (Dendrogyra cylindrus) following two consecutive hyperthermal events on the Florida Reef Tract. Coral Reefs 36, 427-431. doi: 10.1007/s00338-0171545-1

Lirman, D., and Fong, P. (2007). Is proximity to land-based sources of coral stressors an appropriate measure of risk to coral reefs? An example from the Florida Reef Tract. Mar. Pollut. Bull. 54, 779-791. doi: 10.1016/j.marpolbul. 2006.12.014

Mähl, P., Cliquet, F., Guiot, A.-L., Niin, E., Fournials, E., Saint-Jean, N., et al. (2014). Twenty year experience of the oral rabies vaccine SAG2 in wildlife: a global review. Vet. Res. 45, 1-17.

Manzello, D. P., Enochs, I. C., Kolodziej, G., and Carlton, R. (2015). Recent decade of growth and calcification of Orbicella faveolata in the Florida Keys: an inshore-offshore comparison. Mar. Ecol. Prog. Ser. 521, 81-89. doi: 10.3354/ meps11085

Maynard, J., Van Hooidonk, R., Eakin, C. M., Puotinen, M., Garren, M., Williams, G., et al. (2015). Projections of climate conditions that increase coral disease susceptibility and pathogen abundance and virulence. Nat. Clim. Change 5, 688-694. doi: 10.1038/nclimate2625

Meiling, S., Muller, E. M., Smith, T. B., and Brandt, M. E. (2020). 3D photogrammetry reveals dynamics of stony coral tissue loss disease (SCTLD) lesion progression across a thermal stress event. Front. Mar. Sci. 7:597643.

Meyer, J. L., Castellanos-Gell, J., Aeby, G. S., Häse, C., Ushijima, B., and Paul, V. J. (2019). Microbial community shifts associated with the ongoing stony coral tissue loss disease outbreak on the Florida Reef Tract. Front. Microbiol. 10, 22-44. doi: 10.3389/fmicb.2019.02244

Miller, C. V., May, L. A., Moffitt, Z. J., Burnett, A. R., and Woodley, C. M. (2018). Pillar Coral - Dendrogyra cylindrus White Plague-like Disease: Exploratory Treatments. Charleston, SC: NOAA.

Miller, M., Lohr, K., Cameron, C., Williams, D., and Peters, E. (2014). Disease dynamics and potential mitigation among restored and wild staghorn coral, Acropora cervicornis. PeerJ 2:e541. doi: 10.7717/peerj.541

Muller, E., and Van Woesik, R. (2009). Shading reduces coral-disease progression. Coral Reefs 28, 757-760. doi: 10.1007/s00338-009-0504-X

Muller, E. M., Sartor, C., Alcaraz, N. I., and Van Woesik, R. (2020). Spatial epidemiology of the stony-coral-tissue-loss disease in Florida. Front. Mar. Sci. $7: 163$.

Neely, K. L. (2018). Coral Disease Intervention Action Plan. Miami, FL: Florida DEP.

Neely, K. L., Lewis, C. L., Lunz, K. S., and Kabay, L. (2021). Rapid population decline of the pillar coral Dendrogyra cylindrus along the Florida Reef Tract. Front. Mar. Sci. 8:656515. doi: 10.3389/fmars.2021.656515

Neely, K. L., Macaulay, K. A., Hower, E. K., and Dobler, M. A. (2020). Effectiveness of topical antibiotics in treating corals affected by Stony Coral Tissue Loss Disease. PeerJ 8:e9289. doi: 10.7717/peerj.9289

Patterson, K. L., Porter, J. W., Ritchie, K. E., Polson, S. W., Mueller, E., Peters, E. C., et al. (2002). The etiology of white pox, a lethal disease of the Caribbean elkhorn coral, Acropora palmata. Proc. Natl. Acad. Sci. U.S.A. 99, 8725-8730. doi: 10.1073/pnas.092260099

Precht, W. F., Gintert, B. E., Robbart, M. L., Fura, R., and Van Woesik, R. (2016). Unprecedented disease-related coral mortality in Southeastern Florida. Sci. Rep. 6:31374.

R Development Core Team (2013). R: A Language and Environment for Statistical Computing. Vienna: R Foundation for Statistical Computing.

Randall, C., Whitcher, M. E., Code, T., Pollock, C., Lundgren, I., Hillis-Starr, Z., et al. (2018). Testing methods to mitigate Caribbean yellow-band disease on Orbicella faveolata. PeerJ 6:e4800. doi: 10.7717/peerj.4800
Randall, C. J., and van Woesik, R. (2015). Contemporary white-band disease in Caribbean corals driven by climate change. Nat. Clim. Change 5, 375-379. doi: $10.1038 /$ nclimate2530

Richardson, L. L. (1998). Coral diseases: what is really known? Trends Ecol. Evol. 13, 438-443. doi: 10.1016/s0169-5347(98)01460-8

Rohr, J. R., Civitello, D. J., Halliday, F. W., Hudson, P. J., Lafferty, K. D., Wood, C. L., et al. (2020). Towards common ground in the biodiversitydisease debate. Nat. Ecol. Evol. 4, 24-33. doi: 10.1038/s41559-0191060-6

Rosales, S. M., Clark, A. S., Huebner, L. K., Ruzicka, R. R., and Muller, E. (2020). Rhodobacterales and Rhizobiales are associated with Stony Coral Tissue Loss Disease and its suspected sources of transmission. Front. Microbiol. 11:681.

Ruzicka, R. R., Colella, M. A., Porter, J. W., Morrison, J. M., Kidney, J. A., Brinkhuis, V., et al. (2013). Temporal changes in benthic assemblages on Florida Keys reefs 11 years after the 1997/1998 El Nino. Mar. Ecol. Prog. Ser. 489, 125-141. doi: 10.3354/meps 10427

Sharp, W. C., Shea, C. P., Maxwell, K. E., Muller, E. M., and Hunt, J. H. (2020). Evaluating the small-scale epidemiology of the stony-coral -tissue-loss-disease in the middle Florida Keys. PLoS One 15:e0241871. doi: 10.1371/journal.pone. 0241871

Sing, T., Sander, O., Beerenwinkel, N., and Lengauer, T. (2005). ROCR: visualizing classifier performance in R. Bioinformatics 21, 3940-3941. doi: 10.1093/ bioinformatics/bti623

Skoda, S. R., Phillips, P. L., and Welch, J. B. (2018). Screwworm (Diptera: Calliphoridae) in the United States: response to and elimination of the 20162017 outbreak in Florida. J. Med. Entomol. 55, 777-786. doi: 10.1093/jme/ tjy049

Somerfield, P., Jaap, W., Clarke, K., Callahan, M., Hackett, K., Porter, J., et al. (2008). Changes in coral reef communities among the Florida Keys, 1996-2003. Coral Reefs 27, 951-965. doi: 10.1007/s00338-008-0390-7

Squires, D. F. (1965). Neoplasia in a coral? Science 148, 503-505. doi: 10.1126/ science.148.3669.503

Sterner, R. T., Meltzer, M. I., Shwiff, S. A., and Slate, D. (2009). Tactics and economics of wildlife oral rabies vaccination, Canada and the United States. Emerg. Infect. Dis. 15:1176. doi: 10.3201/eid1508.081061

Sweet, M. J., Croquer, A., and Bythell, J. C. (2014). Experimental antibiotic treatment identifies potential pathogens of white band disease in the endangered Caribbean coral Acropora cervicornis. Proc. R. Soc. B Biol. Sci. 281:94.

Tackmann, K., Löschner, U., Mix, H., Staubach, C., Thulke, H. H., Ziller, M., et al. (2001). A field study to control Echinococcus multilocularis infections of the red fox (Vulpes vulpes) in an endemic focus. Epidemiol. Infect. 127, 577-587. doi: $10.1017 / \mathrm{s} 0950268801006112$

Thome, P. E., Rivera-Ortega, J., Rodríguez-Villalobos, J. C., Cerqueda-García, D., Guzmán-Urieta, E. O., García-Maldonado, J. Q., et al. (2021). Local dynamics of a white syndrome outbreak and changes in the microbial community associated with colonies of the scleractinian brain coral Pseudodiploria strigosa. PeerJ 9:e10695. doi: 10.7717/peerj.10695

Thurber, R. L. V., Burkepile, D. E., Fuchs, C., Shantz, A. A., Mcminds, R., and Zaneveld, J. R. (2014). Chronic nutrient enrichment increases prevalence and severity of coral disease and bleaching. Glob. Change Biol. 20, 544-554. doi: $10.1111 /$ gcb. 12450

Vega-Rodriguez, M., Müller-Karger, F., Hallock, P., Quiles-Perez, G., Eakin, C., Colella, M., et al. (2015). Influence of water-temperature variability on stony coral diversity in Florida Keys patch reefs. Mar. Ecol. Prog. Ser. 528, 173-186. doi: 10.3354/meps11268

Walton, C. J., Hayes, N. K., and Gilliam, D. S. (2018). Impacts of a regional, multiyear, multi-species coral disease outbreak in Southeast Florida. Front. Mar. Sci. 5:323. doi: 10.3389/fmars.2018.00323

Weil, E., Hernández-Delgado, E., Gonzalez, M., Williams, S., Suleimán-Ramos, S., Figuerola, M., et al. (2019). Spread of the new coral disease "SCTLD" into the Caribbean: implications for Puerto Rico. Reef Encounter 34, $38-43$.

Williams, G. (2013). Contrasting recovery following removal of growth anomalies in the corals Acropora and Montipora. Dis. Aquat. Organ. 106, 181-185. doi: $10.3354 /$ dao02652 
Williams, S. D., Walter, C. S., and Muller, E. M. (2021). Fine scale temporal and spatial dynamics of the stony coral tissue loss disease outbreak within the lower Florida Keys. Front. Mar. Sci. 8:631776. doi: 10.3389/fmars.2021.631776

Conflict of Interest: The authors declare that the research was conducted in the absence of any commercial or financial relationships that could be construed as a potential conflict of interest.

Publisher's Note: All claims expressed in this article are solely those of the authors and do not necessarily represent those of their affiliated organizations, or those of the publisher, the editors and the reviewers. Any product that may be evaluated in this article, or claim that may be made by its manufacturer, is not guaranteed or endorsed by the publisher.

Copyright (๑) 2021 Neely, Shea, Macaulay, Hower and Dobler. This is an open-access article distributed under the terms of the Creative Commons Attribution License (CC BY). The use, distribution or reproduction in other forums is permitted, provided the original author(s) and the copyright owner(s) are credited and that the original publication in this journal is cited, in accordance with accepted academic practice. No use, distribution or reproduction is permitted which does not comply with these terms. 